Texas A\&M University-San Antonio

Digital Commons @ Texas A\&M University- San Antonio

$11-2019$

\title{
Geometric Morphometric Analyses Support Incorporating the Goshen Point Type into Plainview
}

\author{
Briggs Buchanan \\ University of Tulsa \\ Mark Collard \\ Simon Fraser University \\ Michael J. O'Brien \\ Texas A\&M University-San Antonio, Mike.Obrien@tamusa.edu
}

Follow this and additional works at: https://digitalcommons.tamusa.edu/hist_faculty

Part of the Archaeological Anthropology Commons

\section{Repository Citation}

Buchanan, Briggs; Collard, Mark; and O'Brien, Michael J., "Geometric Morphometric Analyses Support Incorporating the Goshen Point Type into Plainview" (2019). History Faculty Publications. 27.

https://digitalcommons.tamusa.edu/hist_faculty/27

This Article is brought to you for free and open access by the College of Arts and Sciences at Digital Commons @ Texas A\&M University- San Antonio. It has been accepted for inclusion in History Faculty Publications by an authorized administrator of Digital Commons @ Texas A\&M University- San Antonio. For more information, please contact deirdre.mcdonald@tamusa.edu. 


\title{
GEOMETRIC MORPHOMETRIC ANALYSES SUPPORT INCORPORATING THE GOSHEN POINT TYPE INTO
}

\author{
PLAINVIEW
}

Briggs Buchanan, Mark Collard, and Michael J. O’Brien

Briggs Buchanan Department of Anthropology, University of Tulsa, Tulsa, OK 74104, USA (briggs-buchanan@utulsa.edu, corresponding author).

Mark Collard Department of Archaeology, Simon Fraser University, Burnaby, British Columbia V5A 1S6, CANADA.

Michael J. O'Brien Department of Humanities and Social Sciences, Texas A\&M University-San Antonio, San Antonio, TX 78224, USA (Mike.Obrien@tamusa.edu, corresponding author). 
Recent work has demonstrated that Goshen points overlap in time with another group of unfluted lanceolate points from the Plains, Plainview points. This has raised the question of whether the two types should be kept separate or consolidated into a single type. We sought to resolve this issue by applying geometric morphometric methods to a sample of points from well-documented Goshen and Plainview assemblages. We found that their shapes were statistically indistinguishable, which indicates that Goshen and Plainview points should be assigned to the same type. Because Plainview points were recognized before Goshen points, it is the latter type-name that should be dropped. Sinking Goshen into Plainview allows us to move beyond taxonomic issues and toward understanding the spatiotemporal variation that exists among Plainview assemblages and what it can tell us about the adaptations and social dynamics of Plainview groups. 
El trabajo reciente de citas ha demostrado que Goshen apunta se superponen en el tiempo con otro grupo de puntos lanceolados sin fluir de los puntos Plains, Plainview. Esto ha planteado la cuestión de si los dos tipos deben mantenerse separados o consolidados en un solo tipo. Buscamos resolver este problema mediante la aplicación de métodos morfométricos geométricos a una muestra de puntos de los bien documentados ensamblajes de Goshen y Plainview. Encontramos que sus formas fueron estadísticamente indistinguibles, y sugerimos que los puntos de Goshen y Plainview se asignen al mismo tipo. Debido a que los puntos de Plainview se reconocieron antes que los puntos de Goshen, es el último nombre de tipo el que debe abandonado. Sumergir a Goshen en Plainview nos permite ir más allá de los problemas taxonómicos y tratar de comprender la variación espaciotemporal que existe entre los conjuntos de Plainview y lo que puede decirnos acerca de las adaptaciones y la dinámica social de los grupos de Plainview. 
Goshen is a type of Paleoindian projectile point that is lanceolate, has parallel to slightly convex or concave sides and a concave base, and exhibits well-controlled and evenly spaced pressure-flake scars (Bradley and Frison 1996; Irwin-Williams et al. 1973). Goshen points have been recovered as surface finds across much of the Northern Plains and are also known from five well-documented sites (Figure 1): Hell Gap in Wyoming (Irwin 1967; Irwin-Williams et al. 1973; Larson et al. 2009), Mill Iron in Montana (Frison 1996a), Upper Twin Mountain in Colorado (Kornfeld and Frison 2000), Jim Pitts in South Dakota (Sellet et al. 2009), and Dilts in Wyoming (LaBelle 2007).

Figure 1

The type specimen for Goshen was found at Hell Gap. As excavations were coming to a close in August 1966, the field crew found an unfluted lanceolate point and point fragments below the Folsom level (Irwin-Williams et al. 1973). The specimens resembled Plainview points from the Southern Plains, but there was a problem: Received wisdom at the time was that Plainview postdated Folsom, which in turn postdated Clovis. Thus, the excavators reasoned that the Hell Gap specimens could not be Plainview points. Their stratigraphic context suggested they were transitional between Clovis and Folsom, or perhaps that they were unfluted Clovis points (Frison 1991). To circumvent this apparent problem, the excavators of Hell Gap proposed a new complex name, Goshen. 
Several decades later, that small collection of Goshen specimens was supplemented by a larger excavated assemblage of points from Mill Iron, a camp area and bison-bone bed (Frison 1996a; Haynes 1992). There was a strong resemblance between the points from Mill Iron and Plainview points, but, like with Hell Gap, there was a chronological problem: Radiocarbon dates from Mill Iron overlapped not only with the then-known age of Folsom but also with that of Clovis, so much so that it was thought that perhaps Clovis and Folsom developed out of Goshen, with Plainview evolving out of Goshen later than Clovis and Folsom and retaining many of the features its ancestor possessed, including a lack of fluting (Frison 1996a).

Another possibility was that Goshen points and Plainview points were actually the same typologically and that the early radiocarbon assays from Mill Iron did not date the human occupation of the site, perhaps due to contamination or the use of old wood by the inhabitants (Frison 1996b; Haynes and Hill 2017). In line with this argument, Frison et al. (1996) proposed the type name Goshen-Plainview for the unfluted lanceolate points from Mill Iron, arguing that "until the true chronological position of Goshen as pre-Folsom on the Northern Plains and as post-Folsom on the Southern Plains is resolved, the two terms are needed. This can always be changed when new data demand a change" (p. 215).

A number of attempts have been made to resolve Goshen chronology. Waters and Stafford (2014) assayed XAD-purified collagen extracted from three bison bones from Mill Iron and arrived at a date range of 12,525-12,120 cal BP (calendar years before present). Carlson et al. (2016) added two additional bone-collagen dates for Mill Iron, both falling in the range indicated by the Waters and Stafford (2014) assays. Dates on bison bone from a kill at Upper Twin Mountain produced a comparable age range 
(Kornfeld and Frison 2000). Those dates, in turn, are in line with charcoal-based dates from the Goshen component at Jim Pitts, which are slightly younger than the Goshen component at Upper Twin Mountain. Another date, derived from a bison-skull fragment from Dilts, overlaps with the age of Jim Pitts (LaBelle 2007).

Based on their analysis of available dates from Goshen assemblages, Waters and Stafford (2014) suggested that the calendrical span of Goshen was ca. 12,500-11,800 cal BP and that the tradition appeared sometime after the beginning of Folsom, ca. 12,700 cal $\mathrm{BP}$, and continued into the post-Folsom period (ca. post-12,200 cal BP). Waters and Stafford (2014) noted that the chronological overlap helps explain the stratigraphic position of Goshen below Folsom at Hell Gap and also at Carter/Kerr-McGee in northeastern Wyoming (Frison 1984; Frison et al. 1996).

Waters and Stafford (2014:547) noted that "this new dating of the Goshen complex also seems to bring Goshen and the typologically similar Plainview points ... into a similar time horizon; however, Plainview remains poorly dated." This is correct; Plainview has been notoriously difficult to date. Based on samples from four sites in Texas_-Bonfire Shelter, Lubbock Lake, Lake Theo, and Williamson-PlainviewHolliday, Johnson, and Miller (2017) proposed that the minimum age range for Plainview is ca. 12,100-11,300 cal BP and that there is evidence of temporal overlap between Folsom and Plainview at Bonfire Shelter, similar to the situation at Hell Gap and Carter/Kerr-McGee with respect to Folsom and Goshen.

There thus appears to be a north-south chronological gradient for Goshen and Plainview, with Goshen (12,500-11,800 cal BP) beginning earlier than Plainview (12,100-11,300 cal BP) and Plainview lasting longer than Goshen, with perhaps a 300- 
year overlap between the two. In terms of oldest and youngest dates, Mill Iron, in the north, has the oldest dates (12,515-12,250 cal BP) and Bonfire Shelter, in the south, the youngest (11,935-11,445 cal BP). ${ }^{1}$ Jim Pitts, some $200 \mathrm{~km}$ south of Mill Iron, has a range of 11,955-11,770 cal BP (Waters and Stafford 2014), making it younger than Mill Iron and overlapping with the early half of the Bonfire Shelter date range.

This chronological gradient is interesting for reasons we discuss later, but that discussion hinges on the question of typological similarity: Exactly how similar are Goshen and Plainview points? To address that question, we used geometric morphometric (GM) methods to compare the shapes of complete points from welldocumented Goshen and Plainview sites. We used GM because it has proven markedly more effective at capturing morphological differences among specimens than traditional morphometric techniques (Zelditch et al. 2012). We have used the methods in previous studies of Paleoindian point types (e.g., Buchanan and Collard 2010; Buchanan et al. 2015,2017 ), and we followed similar protocol in the study reported here.

\section{Materials and Methods}

We focused on complete points from well-documented excavated assemblages that previous authors have assigned to the Goshen (including Goshen-Plainview) and Plainview types. We analyzed 17 Goshen points from three sites-Hell Gap, Jim Pitts, and Mill Iron (Table S.1). Our Plainview sample comprised 139 points from five sites in West Texas_Plainview (Holliday, Johnson, and Speer 2017; Sellards et al. 1947) and Ryan's Site (Hartwell 1995) — and three in New Mexico-Milnesand (Hill 2002; Sellards 1955; Warnica and Williamson 1968), Williamson-Plainview (also known as Ted 
Williamson [Buchanan et al. 1996]), and Warnica-Wilson (also known as Bethel [Reutter 1996]) (Figure 1). We did not include points from Dilts, Bonfire Shelter (Texas), or Upper Twin Mountain because it was logistically impossible for us to visit the collections.

We imported photos of the points into digitizing software (Rohlf 2017) and placed landmarks around the perimeters of the points. To make the analysis comparable to previous studies (e.g., Buchanan et al. 2015, 2017), we used 23 landmarks to define the outline of each point. Three landmarks (one at the tip and two defining the basal edges) were deemed homologous, and 20 landmarks were placed along the blade and basal edges using equally spaced line segments superimposed on the images and placed between the tip and basal landmarks (Figure 2). Overall point shape incorporates many of the attributes that have been traditionally used to distinguish among types-including Goshen, Plainview, and related forms - such as basal-concavity depth and shape (Haynes and Hill 2017; Hester 2017; Rondeau et al. 2017), blade shape (Buchanan and Collard 2010), and base shape (O’Brien et al. 2014).

Figure 2

Next, using MorphoJ version 1.06d software (Klingenberg 2011), we carried out a generalized Procrustes analysis (GPA) on the landmark configurations (Bookstein 1991). For the GPA, landmark coordinates were aligned to remove nonshape sources 
(translation, scaling, and rotation) and to extract shape (Procrustes coordinates) information from the landmark configurations. MorphoJ uses the full Procrustes algorithm and projects the data to the tangent space (a linear space that locally approximates the shape space) by orthogonal projection (Klingenberg 2011).

We applied MorphoJ's principal components analysis (PCA) to the variance and covariance matrices to examine patterns of shape variation and used discriminant function analysis (DFA) to statistically examine the degree of separation between the two predefined groups, with "predefined" referring to how a point was identified in the original publications. We report both the Procrustes and Mahalanobis distances and the associated permutation tests of these distances. The former describes the total shape change from the consensus landmark configuration, and the latter is the distance between the types scaled by the within-group standard deviation in the respective direction. Klingenberg and Monteiro (2005) determined that cases where the $p$-values for these tests using the two types of distances differ, it is primarily a consequence of the variation within groups - here shape variation - going in different directions (anisotropy). Following the DFA, we used the cross-validated misclassification matrix to assess misclassification rates (Kovarovic et al. 2011). A high rate of misclassification corresponds to a limited ability to distinguish among the groups, in this case point types.

\section{Results}

The landmark configurations shown in Figure 3, which are averages of the individual measurements (shown), demonstrate there is considerable overlap between the shapes of Goshen and Plainview points. Only two, minor differences are discernible: the average 
Goshen point has a somewhat narrower blade than the average Plainview point, and the average Goshen point has a slightly more triangular basal concavity than the average Plainview point. These similarities and slight differences in shape were picked up in the PCA, which indicated that the first two components accounted for most of the variation (88\%) in the dataset (Figure 4). Sixteen of the 17 Goshen points fell within the 95\% confidence ellipse for Plainview on the first principal component, while the two groups of points overlapped completely on the second principal component. Thus, the PCA indicates there is no difference between Goshen and Plainview points.

Figures 3 and 4

The DFA analyses were more ambiguous. The DFA based on Mahalanobis distances indicated that the distance between the Goshen and Plainview samples was not statistically significant $(D=2.34$; permutation test $p=0.0749)$. In contrast, the Procrustes distance between the Goshen and Plainview points was statistically significant (Procrustes distance $=0.051$; permutation $p=0.0148$ ). The cross-validated classification matrix was consistent with the PCA and Mahalanobis distance-based DFA. It also indicated substantial overlap between the shapes of the Goshen and Plainview points. Goshen points were misclassified as Plainview points $41 \%$ of the time (seven misclassified out of 17), while Plainview points were misclassified as Goshen points $20 \%$ of the time (28 misclassified out of 139). The overall misclassification rate was $22 \%$. 


\section{Discussion}

Overall, results of the analyses indicate that the shapes of Goshen and Plainview points are very similar. There was considerable overlap in the distributions of the samples when the average shapes and the first two PCs were plotted (Figures 3 and 4); the Mahalanobis distance between the two samples was insignificant; and there was a high rate of misclassification in the cross-validation analysis. However, because the permutation test of the Procrustes distances returned a significant result, there remains some uncertainty about whether the two point types should be kept separate or merged.

One way to decide which option is more appropriate is to compare the Goshen versus Plainview Procrustes distance with Procrustes distances between other Paleoindian point types. Recently, Buchanan et al. (2018) computed the distance between a sample of Clovis points and a sample of Folsom points using the same set of landmarks and geometric techniques as those employed here. Clovis and Folsom points have wellestablished shape and typological differences (Wormington 1957), and therefore the distance between them represents a useful yardstick for assessing the importance of the Goshen versus the Plainview Procrustes distance (0.051). The value reported by Buchanan and colleagues was 0.159 (permutation test $p<0.0001$ ). Thus, the distance separating their samples of Clovis and Folsom points is over three times larger than the distance separating our samples of Plainview and Goshen points.

The Goshen versus Plainview Procrustes distance can also be usefully compared to a distance that Buchanan et al. (2017) obtained in a study in which they compared the shapes of Milnesand, Plainview, and Lubbock points. The shapes of Milnesand and 
Plainview points were so similar that the recommendation was made that they should be treated as a single type. The Procrustes distance that Buchanan and colleagues reported for their Milnesand versus Plainview comparison was 0.095 , which is also considerably larger than the Goshen versus Plainview distance of 0.051 .

Given these results, there appear to be grounds for viewing Goshen as typologically unimportant. This means that the results of each analysis reported here support the idea that Goshen and Plainview represent a single point type. Because the Plainview type was recognized before the Goshen type (Sellards et al. 1947), the type name Plainview has priority and the type name Goshen should be retired.

Haynes and Hill (2017), who used linear dimensions and ratios to compare Goshen points from Mill Iron to Plainview points from the Plainview type site, also suggested that the Goshen type name should be abandoned in favor of Plainview. Similarly, Bradley and Frison (1996:66) argued that whereas the Mill Iron points could be classified as Goshen, "they are basically the same, technologically and typologically as Plainview." Their only reservation was the apparent age difference between the two types, but as we explained earlier, that issue now seems to have been resolved.

Beyond the similar age and shape of Goshen and Plainview points, future analyses should address if similarities also exist in flaking patterns. Bradley (2010) noted differences in the amount of pressure flaking used on the Plainview type points and the Goshen points from Mill Iron, suggesting that the Mill Iron points exhibit more transmedial and comedial pressure flaking than do the points from the Plainview type site. However, others have suggested that Goshen points from Mill Iron lack regular 
pressure flaking (Sellet et al. 2009). Future systematic work should clear up any confusion.

Sinking Goshen into Plainview allows us to move beyond typological issues and examine the nature and causes of the variation that exists among Plainview points, especially chronospatial variation. We indicated earlier that there appears to be a northsouth, older-to-younger chronological gradient for what we are calling Plainview points - again, comprising points previously typed as Plainview, Goshen, GoshenPlainview, and Milnesand — starting in the north with Mill Iron (12,515-12,250 cal BP), moving south to Jim Pitts (11,955-11,700 cal BP), and finally farther south to Bonfire Shelter $(11,935-11,445$ cal BP). Thus, the limited reliable radiocarbon evidence that is currently available (we exclude dates from the Plainview site because of their unreliability [Holliday, Johnson, and Speer 2017]) indicates that the Plainview tradition arose at or near Mill Iron on the Northern Plains during the waning centuries of the Folsom tradition and then spread south, reaching Jim Pitts by 11,955 calBP and Bonfire Shelter by 11,935 calBP.

This movement could have occurred through cultural diffusion (movement of ideas), demic expansion (movement of people), or both. Interestingly, the north-to-south movement has similarities with the situation with Folsom, which according to Collard et al. (2010) appeared first around 12,800 cal BP in the northern High Plains - perhaps around Hell Gap — and spread north and south from there (but see Jennings 2012). Collard et al.'s (2010) summed probability distributions of calibrated radiocarbon dates suggested that above $36^{\circ} \mathrm{N}$ latitude, Folsom technology could have spread through either demic expansion or cultural diffusion (or a combination of the two), but below $36^{\circ} \mathrm{N}$ it 
appears to have spread through the former, as there is a hiatus between Clovis and Folsom radiocarbon dates from the Southern Plains.

Distinguishing between demic expansion and cultural diffusion in the archaeological record is particularly difficult in cases where there is evidence of diffusion of a novel trait into a region that has evidence of a population already in place (Smith and Goebel 2018). The radiocarbon resolution for Plainview is not good enough to resolve the issue, but we suspect that demic expansion did not play a significant role in its dispersal. We say this because bison-hunting groups were already spread across the Northern and Southern Plains and, during at least a portion of the Folsom period, were making unfluted points, termed Midland, alongside fluted points (Hofman 1992).

The spatiotemporal overlap in point types should not be surprising when the transition of types is understood within a social-learning framework (Eren et al. 2015; O'Brien and Buchanan 2017). Although point types are useful as time markers and as windows into technological traditions, we need to move away from the notion that people produced one form, then another, and so on in a unilinear evolutionary sequence (Holliday, Johnson, and Knudson 2017). Rather, forms often overlapped in timedemonstrated by Plainview, Folsom, and Midland — as new innovations were adopted in certain regions as a result of selection and drift working on different portions of points (O'Brien 2019; Smith et al. 2015). For example, in their phylogenetic analysis of Paleoindian points from the Southeast, Smallwood et al. (2019) found clear evidence that point bases, blades, and end-thinning techniques did not evolve as a package. Rather, each had its own trajectory, subject, at least in part, to different evolutionary forces-a case of mosaic evolution. Similarly, our study of the modularity of Clovis and Folsom 
points from the Northern and Southern Plains (Buchanan et al. 2018) showed that Folsom bases and blades are less variable than those of Clovis, which suggests that point standardization increased during the Early Paleoindian period in western North America.

In conclusion, when it comes to projectile-point typology, we walk a fine line: too many types and we create utter confusion; too few and we compress variation that could help address chronological, cultural, and technological matters. This issue has a deep history in American archaeology (O'Brien and Lyman 1999). The decades-long discussion of the typological placement not only of Goshen and Plainview but of all Late Pleistocene unshouldered lanceolate points from the Northern and Southern Plains is a classic example of the dilemma. As we have shown here, geometric morphometrics offers a way forward.

\section{Acknowledgments.}

We thank Laura Nightengale of the Texas Archeological Research Laboratory, Austin, for access to the Plainview assemblage and portions of the Milnesand and Lubbock Lake assemblages collected by E. H. Sellards. The late Ted Williamson and his son, Ted Williamson, Jr., graciously permitted analysis of their personal collections of the Milnesand and Ted Williamson-Plainview sites, as did James Warnica with the WarnicaWilson assemblage and his surface collection from Roosevelt County, New Mexico. We also thank Eileen Johnson of the Museum of Texas Tech University for access to the Ryan's Site collections. Finally, we thank Lynn Gamble and three anonymous reviewers for their suggestions on how to improve the manuscript. Our work was supported by the 
Canada Research Chairs Program (231256), the Canada Foundation for Innovation (36801), and the British Columbia Knowledge Development Fund (962-805808).

Data Availability Statement. The data used in this paper are available in the Supplemental Materials.

Supplemental Materials. For supplementary material accompanying this paper, visit -----. Supplemental Excel file: Goshen and Plainview point specimens in analyses, Procrustes fit, PCA eigenvalues, PC coefficients. 


\section{References Cited}

Bookstein, Fred L.

1991 Morphometric Tools for Landmark Data: Geometry and Biology.

Cambridge University Press, Cambridge.

Bradley, Bruce A.

2010 Paleoindian Flaked Stone Technology on the Plains and in the Rockies. In Prehistoric Hunter-Gatherers of the High Plains and Rockies, 3rd ed., edited by Marcel Kornfeld, George C. Frison, and Mary Lou Larson, pp. 463-497. Left Coast Press, Walnut Creek, California.

Bradley, Bruce A., and George C. Frison

1996 Flaked-Stone and Worked-Bone Artifacts from the Mill Iron Site. In The Mill Iron Site, edited by George C. Frison, pp. 43-69. University of New Mexico Press, Albuquerque.

Buchanan, Briggs, and Mark Collard 2010 A Geometric Morphometrics-Based Assessment of Blade Shape Differences among Paleoindian Projectile Point Types from Western North America. Journal of Archaeological Science 37:350-359.

Buchanan, Briggs, Michael J. O’Brien, and Mark Collard 2017 A Geometric Morphometrics-Based Assessment of Point Types on the Southern High Plains during Plainview Times. In Plainview: The Enigmatic Paleoindian Artifact Style of the Great Plains, edited by Vance T. Holliday, Eileen Johnson, and Ruthann Knudson, pp. 274-284. University of Utah Press, Salt Lake City. 
Buchanan, Briggs, Brian Andrews, Michael J. O’Brien, and Metin I. Eren 2018 An Assessment of Stone Weapon Tip Standardization during the ClovisFolsom Transition in the Western United States. American Antiquity 83:721-734. Buchanan, Briggs, Metin I. Eren, Matthew T. Boulanger, and Michael J. O’Brien 2015 Size, Shape, Scars, and Spatial Patterning: A Quantitative Assessment of Late Pleistocene (Clovis) Point Resharpening. Journal of Archaeological Science: Reports 3:11-21.

Buchanan, Briggs, Luc Litwinionek, Eileen Johnson, Vance T. Holliday, and J. Kent Hicks 1996 Renewed Investigations at Milnesand and Ted Williamson Paleoindian Sites, Southern High Plains. Current Research in the Pleistocene 13:8-10. Carlson, Kristen A., Brendan J. Culleton, Douglas J. Kennett, and Leland C. Bement 2016 Tightening Chronology of Paleoindian Bison Kill Sites on the Northern and Southern Plains. PaleoAmerica 2:90-98.

Collard, Mark, Briggs Buchanan, Marcus J. Hamilton, and Michael J. O’Brien 2010 Spatiotemporal Dynamics of the Clovis-Folsom Transition. Journal of Archaeological Science 37:2513-2519.

Eren, Metin I., Briggs Buchanan, and Michael J. O'Brien 2015 Social Learning and Technological Evolution during the Clovis Colonization of the New World. Journal of Human Evolution 80:159-170. Frison, George C.

1984 The Carter/Kerr-McGee Paleoindian Site: Cultural Resource Management and Archaeological Research. American Antiquity 49:288-314. 
Frison, George C.

1991 Prehistoric Hunters of the High Plains. 2nd. ed. Academic Press, San Diego.

Frison, George C. (editor)

1996a The Mill Iron Site. University of New Mexico Press, Albuquerque.

Frison, George C.

1996b Introduction. In The Mill Iron Site, edited by George C. Frison, pp. 1-13. University of New Mexico Press, Albuquerque.

Frison, George C., C. Vance Haynes, Jr., and Mary Lou Larson

1996 Discussion and Conclusions. In The Mill Iron Site, edited by George C.

Frison, pp. 205-216. University of New Mexico Press, Albuquerque.

Hartwell, William T.

1995 The Ryan's Site Cache: Comparisons to Plainview. Plains Anthropologist $40: 165-184$.

Haynes, C. Vance, Jr.

1992 Contributions of Radiocarbon Dating to the Geochronology of the Peopling of the New World. In Radiocarbon after Four Decades, edited by Ervin Taylor, Austin Long, and Renee S. Kra, pp. 355-374. Springer, New York. Haynes, C. Vance, Jr., and Matthew E. Hill, Jr.

2017 Plainview-Goshen-Midland Typological Problems. In Plainview: The Enigmatic Paleoindian Artifact Style of the Great Plains, edited by Vance T. Holliday, Eileen Johnson, and Ruthann Knudson, pp. 249-273. University of Utah Press, Salt Lake City. 
Hester, Thomas R.

2017 The St. Mary’s Hall Type: The History, Chronology, and Distribution of St. Mary's Hall Projectile Points. In Plainview: The Enigmatic Paleoindian Artifact Style of the Great Plains, edited by Vance T. Holliday, Eileen Johnson, and Ruthann Knudson, pp. 145-173. University of Utah Press, Salt Lake City.

Hill, Matthew E.

2002 The Milnesand Site: Site Formation Study of a Paleoindian Bison Bonebed in Eastern New Mexico. Plains Anthropologist 47:323-337.

Hofman, Jack L.

1992 Recognition and Interpretation of Folsom Technological Variability on the Southern Plains. In Ice Age Hunters of the Rockies, edited by Dennis J. Stanford and Jane Stevenson Day, pp. 193-224. Denver Museum of Natural History, Denver, Colorado.

Holliday, Vance T., Eileen Johnson, and Ruthann Knudson 2017 Plainview: What We Know and What We Think We Know. In Plainview: The Enigmatic Paleoindian Artifact Style of the Great Plains, edited by Vance T. Holliday, Eileen Johnson, and Ruthann Knudson, pp. 285-292. University of Utah Press, Salt Lake City.

Holliday, Vance T., Eileen Johnson, and D. Shane Miller

2017 Stratigraphic Context and Chronology of Plainview Sites on the Southern Great Plains. In Plainview: The Enigmatic Paleoindian Artifact Style of the Great Plains, edited by Vance T. Holliday, Eileen Johnson, and Ruthann Knudson, pp. 79102. University of Utah Press, Salt Lake City. 
Holliday, Vance T., Eileen Johnson, and Roberta Speer

2017 The Plainview Site: History, Geology and Zooarchaeology. In Plainview: The Enigmatic Paleoindian Artifact Style of the Great Plains, edited by Vance T.

Holliday, Eileen Johnson, and Ruthann Knudson, pp. 1-28. University of Utah Press, Salt Lake City.

Irwin, Henry T.

1967 The Itama: Late Pleistocene Inhabitants of the Plains of the United States and Canada and the American Southwest. PhD dissertation, Department of Anthropology, Harvard University. Cambridge, Massachusetts.

Irwin-Williams, Cynthia, Henry T. Irwin, George Agogino, and C. Vance Haynes, Jr. 1973 Hell Gap: Paleo-Indian Occupation on the High Plains. Plains Anthropologist 18:40-53.

Jennings, Thomas A.

2012 Clovis, Folsom, and Midland Components at the Debra L. Friedkin Site, Texas: Context, Chronology, and Assemblages. Journal of Archaeological Science 39:3239-3247.

Klingenberg, Christian P.

2011 MorphoJ: An Integrated Software Package for Geometric Morphometrics. Molecular Ecology Resources 11:353-357.

Klingenberg, Christian P., and Leandro R. Monteiro

2005 Distances and Directions in Multidimensional Shape Spaces: Implications for Morphometric Applications. Systematic Biology 54:678-688.

Kornfeld, Marcel, and George C. Frison 
2000 Paleoindian Occupation of the High Country: The Case of Middle Park, Colorado. Plains Anthropologist 45:129-153.

Kovarovic, Kris, Leslie C. Aiello, Andrea Cardini, and Charles A. Lockwood

2011 Discriminant Function Analyses in Archaeology: Are Classification Rates Too Good to Be True? Journal of Archaeological Science 38:3006-3018.

LaBelle, Jason M.

2007 The Dilts Site (48CA4718): Goshen and Bison in Eastern Wyoming. Current Research in the Pleistocene 24:114-115.

Larson, Mary Lou, Marcel Kornfeld, and George C. Frison (editors)

2009 Hell Gap: A Stratified Paleoindian Campsite at the Edge of the Rockies.

University of Utah Press, Salt Lake City.

O’Brien, Michael J.

2019 More on Clovis Learning: Individual-Level Processes Aggregate to Form Population-Level Patterns. PaleoAmerica 5:157-168.

O’Brien, Michael J., and Briggs Buchanan

2017 Cultural Learning and the Clovis Colonization of North America. Evolutionary Anthropology 26:270-284.

O’Brien, Michael J., and R. Lee Lyman

1999 Seriation, Stratigraphy, and Index Fossils: The Backbone of Archaeological Dating. Kluwer Academic/Plenum, New York.

O’Brien, Michael J., Matthew T. Boulanger, Briggs Buchanan, Mark Collard, R. Lee Lyman, and John Darwent 
2014 Innovation and Cultural Transmission in the American Paleolithic:

Phylogenetic Analysis of Eastern Paleoindian Projectile-Point Classes. Journal of Anthropological Archaeology 34:100-119.

Reutter, Stacie

1996 A Technological and Typological Study of a Plainview Site on the High Plains of Eastern New Mexico. MA thesis, Department of Anthropology, Eastern New Mexico University. Portales.

Rohlf, F. James

2017 tpsDIG, version 2.31. Department of Ecology and Evolution, State University of New York, Stony Brook. http://life.bio.sunysb.edu/morph.

Rondeau, Michael F., Geoffrey M. Smith, and John W. Dougherty 2017 Discriminating Black Rock Concave Base Points from Other Western Paleoindian Projectile Points. In Plainview: The Enigmatic Paleoindian Artifact Style of the Great Plains, edited by Vance T. Holliday, Eileen Johnson, and Ruthann Knudson, pp. 230-248. University of Utah Press, Salt Lake City.

Sellards, E. H. 1955 Fossil Bison and Associated Artifacts from Milnesand, New Mexico. American Antiquity 20:336-344.

Sellards, E. H., Glen L. Evans, and Grayson E. Meade 1947 Fossil Bison and Associated Artifacts from Plainview, Texas. Bulletin of the Geological Society of America 58:927-954.

Sellet, Frederic, James Donohue, and Matthew G. Hill 
2009 The Jim Pitts Site: A Stratified Paleoindian Site in the Black Hills of South Dakota. American Antiquity 74:735-758.

Smallwood, Ashley M., Thomas A. Jennings, Charlotte D. Pevny, and David G. Anderson

2019 Paleoindian Projectile-Point Diversity in the American Southeast: Evidence for the Mosaic Evolution of Point Design. PaleoAmerica 5:doi.org/10.1080/20555563.2019.1600343.

Smith, Heather L., and Ted Goebel 2018 Origins and Spread of Fluted-Point Technology in the Canadian Ice-Free Corridor and Eastern Beringia. Proceedings of the National Academy of Sciences $115: 4116-4121$.

Smith, Heather L., Ashley M. Smallwood, and Thomas J. DeWitt 2015 Defining the Normative Range of Clovis Fluted Point Shape Using Geographic Models of Geometric Morphometric Variation. In Clovis: On the Edge of a New Understanding, edited by Ashley M. Smallwood and Thomas A. Jennings, pp. 161-180. Texas A\&M University Press, College Station.

Warnica, James M., and Ted Williamson 1968 The Milnesand Site—Revisited. American Antiquity 33:16-24.

Waters, Michael R., and Thomas W. Stafford 2014 Redating the Mill Iron Site, Montana: A Reexamination of Goshen Complex Chronology. American Antiquity 79:541-548.

Wormington, H. Marie 
1957 Ancient Man in North America. Denver Museum of Natural History,

Denver.

Zelditch, Miriam L., Donald L. Swiderski, and H. David Sheets

2012 Geometric Morphometrics for Biologists: A Primer. 2nd. ed. Academic Press, London.

\section{Notes}

${ }^{1}$ For Bonfire Shelter, we used the four calibrated dates reported in Holliday et al. (2017b:Table 3.4B) under "mean probability years BP."

${ }^{2}$ Unfortunately, Plainview points in the Ted Williamson-Plainview and most of the Milnesand assemblages are glued to boards, precluding accurate measurement of thickness. 
Figure 1. Location of sites mentioned in the text: 1, Mill Iron; 2, Carter/Kerr McGee and Dilts; 3, Jim Pitts; 4, Hell Gap; 5, Upper Twin Mountain; 6, Lake Theo; 7, Plainview; 8, Ted Williamson-Plainview, Milnesand, and Warnica-Wilson; 9, Lubbock Lake and Ryan's Site; 10, Bonfire Shelter.

Figure 2. Digital image of a Plainview point with the locations of 23 landmarks marked along the point outline. The lines superimposed on the point image were produced using the MakeFan6 shareware program (www.canisius.edu/ $\sim$ sheets/morphsoft.html) (from Buchanan et al. 2017).

Figure 3. Average landmark configurations for Goshen and Plainview points.

Figure 4. Bivariate plot of principal component scores for component 1 (x-axis), accounting for $81.12 \%$ of the overall variation, and component 2 (y-axis), accounting for $6.76 \%$ of the overall variation, of Goshen (green) and Plainview (blue) points. The 95\% confidence ellipses encompass the Goshen and Plainview variability. 


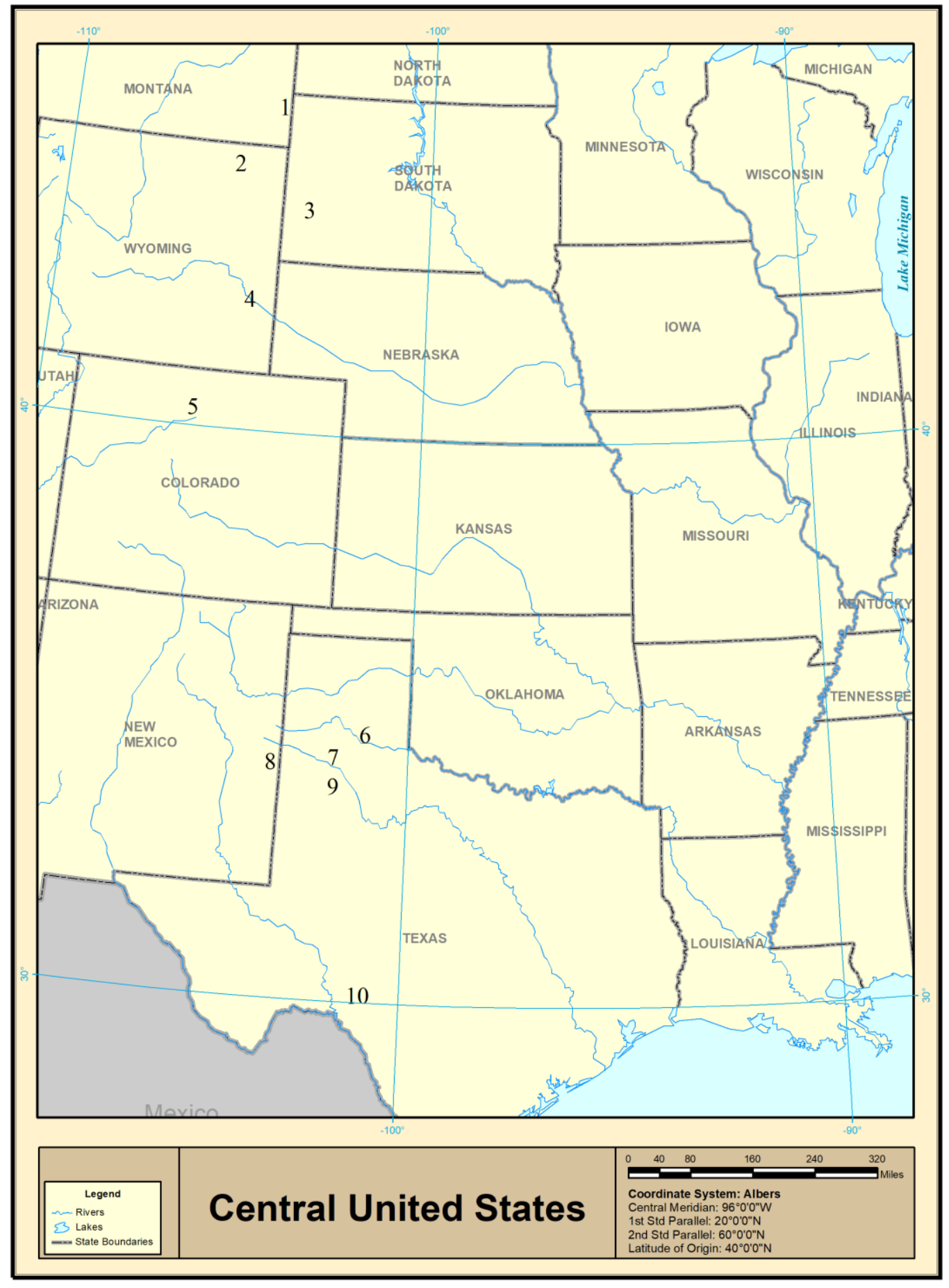

Figure 1. 


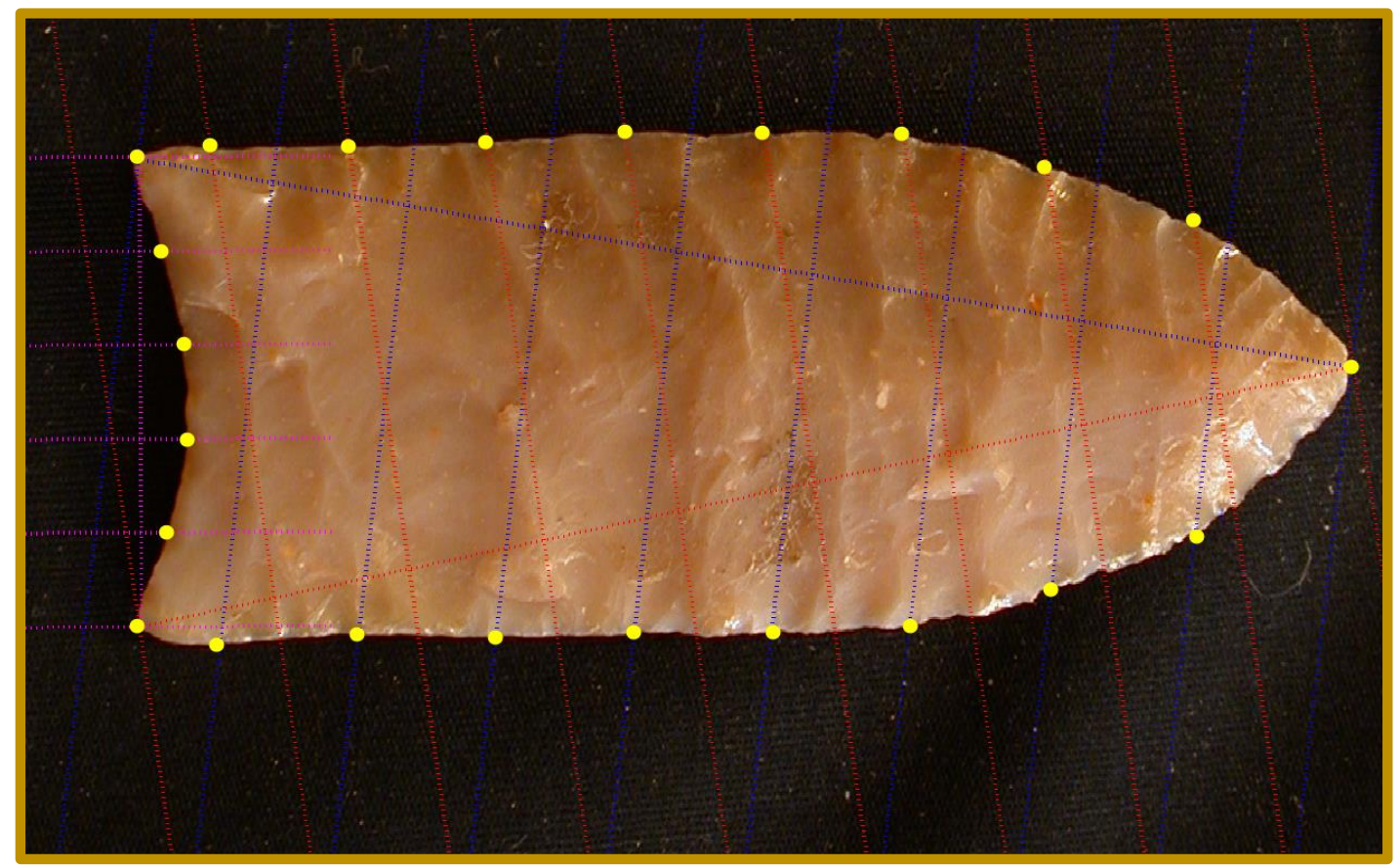

Figure 2. 


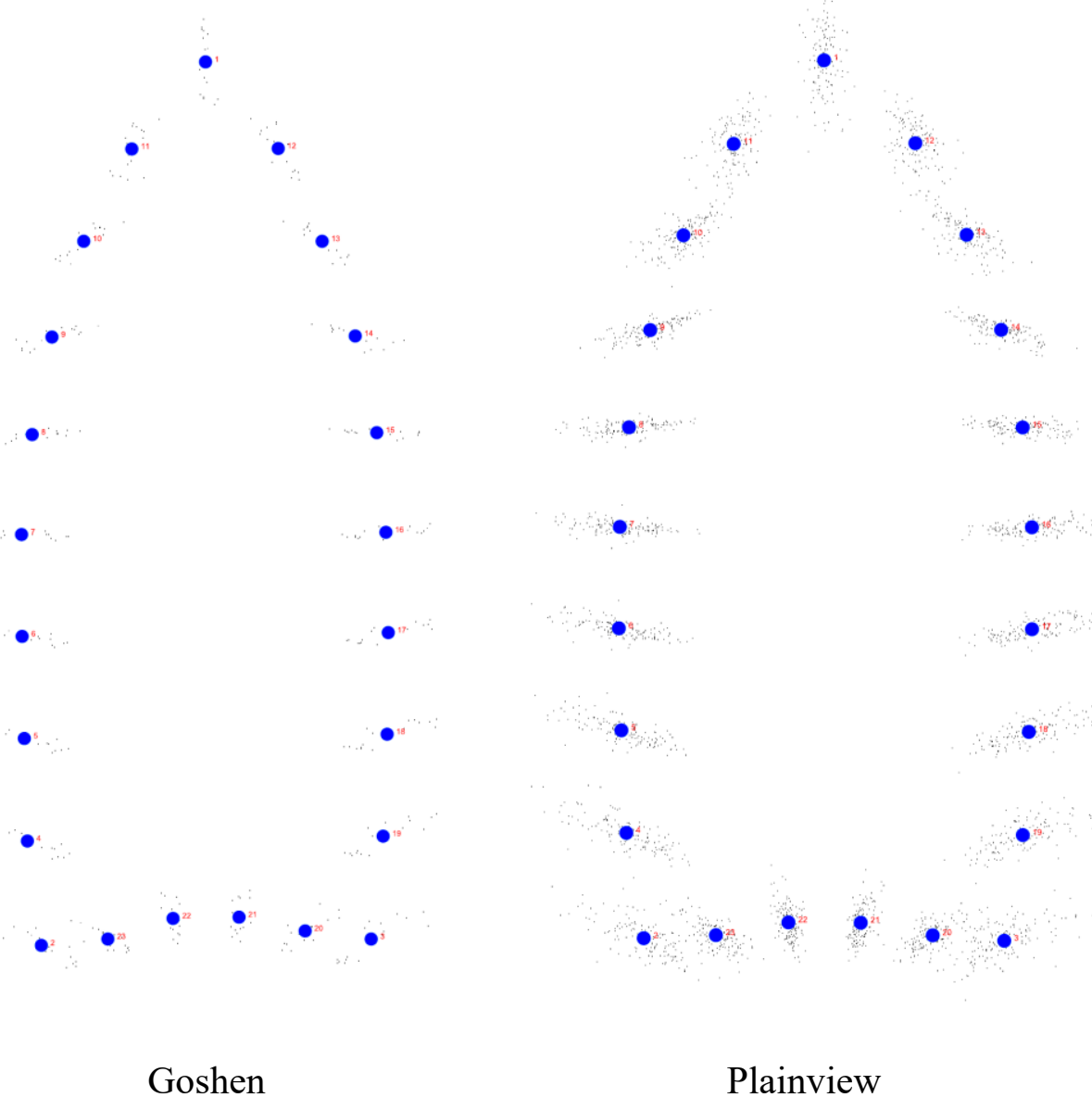

Figure 3. 


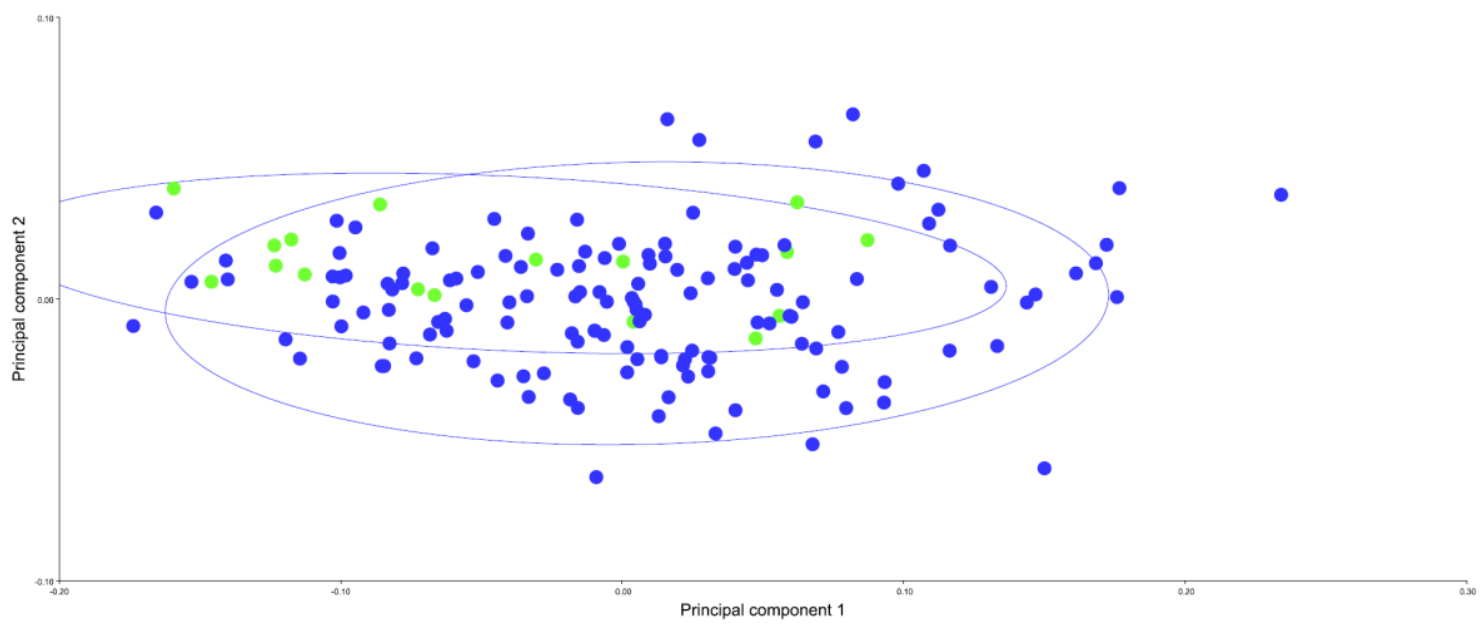

Figure 4. 
Table S.1. Samples of Goshen and Plainview points by site.

\begin{tabular}{llc}
\hline Site & $\begin{array}{c}\text { Previously Assigned } \\
\text { Type Designation }\end{array}$ & $\begin{array}{c}\text { Number of Points } \\
\text { Used }\end{array}$ \\
\hline Hell Gap & Goshen & 1 \\
Mim Pitts & Goshen & 4 \\
Plainview & Goshen-Plainview & 12 \\
Williamson-Plainview & Plainview & 54 \\
Milnesand & Plainview & 39 \\
Ryan's Site & Milnesand & 11 \\
Warnica-Wilson & Plainview & 25 \\
\hline
\end{tabular}

